\title{
KORELASI ANTARA FIXATION EYE TRACKING METRIC DENGAN PERFORMANCE MEASUREMENT USABILITY TESTING
}

\author{
(Correlation Between Fixation Eye Tracking Metric with Performance Measurement Usability Testing)
}

\author{
Yogie Ajie Purnomo*, Tri Suratno, Mauladi
}

Program Studi Sistem Informasi, Fakultas Sains danTeknologi, Universitas Jambi

\begin{abstract}
Not all websites have fulfilled basic principles such as accessible and easy to use (usable). There are several measuring methods that already exist. In this research, the measurement is done by combining two measuring methods namely usability testing and eye tracking because the measurement is done with props that are eye tracking, so that at the same time we can measure the indicator usability testing and eye tracking metrics. So researchers to know the level of relationship or correlation between usability testing indicators and eye tracking metrics. The type of research conducted is a type of associative research with quantitative approaches. these methods will result in quantitative data such as time on task, difficulty ratings, fixation duration mean and time to first fixation. Results of a correlation test Pearson product moment acquired correlation or relationship between time on task with fixation duration mean, time on task with time to first fixation, difficulty ratings with fixation duration mean, difficulty ratings with time to First fixation. There are two possibilities of usability measurement performance indicators with eye tracking proving a significant correlation levels > 2.048 means measurement of usability using eye tracking can be used as an doing making usability measurement more accurately at the next research.
\end{abstract}

Keywords: usability testing, eye tracking, fixation, correlation pearson product moment

\section{PENDAHULUAN}

Produk teknologi informasi seperti situs web dalam menyajikan berbagai kebutuhan informasi dan layanan digital bagi pengguna telah semakin beragam, kreatif dan inovatif. Namun pada kenyataannya saat ini, belum semua situs web telah memenuhi prinsipprinsip dasar seperti mudah diakses (accessible) dan mudah digunakan (usable). Salah satu cara untuk dapat mengetahui seberapa jauh situs web mudah digunakan adalah dengan usability. (Krug, 2010).

Terdapat beberapa metode pengukuran yang sudah ada, diantaranya Usability testing mengevaluasi dengan mengukur seberapa baik kinerjanya dengan akurasi atau efisiensi dan perhatikan jika mereka memenuhi tujuan yang telah ditetapkan. (Tzanidou, 2005), kemudian metode eye tracking digunakan untuk mempelajari gerakan mata yang memberikan informasi tentang interaksi manusia-komputer dan mengetahui fitur mana yang sering dilihat dalam menyelesaikan tugas pengujian, titik waktu, berapa lama mereka melihat sesuatu, dan arah pergerakan mata mereka.

Pengukuran dilakukan dengan alat peraga yang sama yaitu eye tracking, sehingga diwaktu yang bersamaan kita dapat mengukur indikator usability testing dan metrik-metrik eye tracking. Karena alat peraganya sama tentu ada korelasi atau hubungannya tetapi peneliti ingin mencari tau tingkat korelasinya dan apakah antara 2 pengukuran yaitu indikator usability testing dan metrik-metrik eye tracking memiliki hubungan atau korelasi.

Dari penelitian sebelumnya yang dilakukan oleh Jiahui Wang, Pavlo Antonenko, Mehmet Celepkolu, Yerika Jimenez, Ethan Fieldman \& Ashley Fieldman berjudul "Exploring Relationships Between Eye Tracking and Traditional Usability Testing Data" dalam penelitian ini menjelaskan mengidentifikasi hubungan antara metrik Eye Tracking dan Usability tradisional dimana 
terdapat korelasi negatif antara number of fixation dengan difficulty ratings, korelasi positif antara number of fixation dengan time on task dan korelasi negatif antara time on task dengan difficulty ratings. (Wang et al., 2018). Maka dari penelitian yang akan dilakukan adalah mencari korelasi antara dua indikator usability testing dengan metrik eye tracking yang lain yang belum dikorelasikan oleh peneliti sebelumnya seperti time on task dengan fixation duration mean, time on task dengan time to first fixation, difficulty ratings dengan fixation duration mean, difficulty ratings dengan time to first fixation.

Dalam penelitian ini dilakukan pada website yang belum pernah partisipan kunjungi sebelumnya, hal ini untuk mendapatkan hasil yang baik pada saat proses pengukuran berlangsung, jika melakukan pengukuran pada Website yang sudah diketahui pengguna maka pengukuran menjadi tidak maksimal karena mereka mempunyai pengalaman yang lebih soal Website tersebut, tanpa melihat dan tanpa berpikir panjang mereka akan tau letak-letak posisi fitur Website.

Penelitian dilakukan pada Amazon.com yang merupakan website terbesar didunia yang menjual beraneka macam produk yang didirikan pada tahun 1994 oleh Jeff Bezos. Amazon.com memiliki jumlah pengunjung terbanyak sebesar 2,35 milyar pengunjung pada November 2019 dilansir pada halaman similarweb.com dengan total pelanggan aktif sebanyak 310 juta pelanggan.

\section{Tinjauan Pustaka}

\section{Usability}

ISO 9241: 11 (1998) usability adalah sejauh mana suatu produk dapat digunakan oleh pengguna tertentu untuk mencapai target yang ditetapkan dengan effectiveness (keberhasilan dalam penyelesaian tugas), efficiency (waktu yang dibutuhkan pengguna dalam menyelesaikan tugas) dan satisfaction (kepuasan penggunaan). (ISO, 1998).

Tullis dan Albert (2008), waktu penyelesaian tugas dan keberhasilan tidak serta merta menangkap semua elemen yang terkait dengan keefektifan dan efisiensi, untuk menilai atau mengukur kedua indikator tersebut dapat menambahkan atau menggunakan peringkat kesulitan tugas (difficulty ratings). (Tullis and Albert, 2008).

\section{Usability Testing}

Usability testing adalah teknik pengujian yang berpusat pada pengguna yang digunakan untuk mengevaluasi suatu produk dengan mengujinya dengan pengguna yang sebenarnya, pengujian yang dilakukan sampai selesai dan berfokus pada performance measurement atau pengukuran kinerja effesiensi dan efektivitas. (Bergstrom and Schall, 2014).

\section{Eye Tracking}

Andrew Schall (2014), Eye Tracking adalah sebuah metodologi yang digunakan dalam memahami perhatian visual pengguna, dengan adanya proses pelacakan mata ini kita dapat mendeteksi titik perpindahan pergerakan jejak mata setiap waktu, berapa lama waktu saat pengguna melihat sesuatu di area website. (Bergstrom and Schall, 2014). Area Of Interest (AOI) adalah sebuah modul yang digunakan untuk memetakan atau menggambarkan area yang akan diuji. (Voßkühler, 2009). Terdapat beberapa metrik eye tracking seperti jumlah titik fokus atau fiksasi pengguna (number of fixation), rata-rata waktu fiksasi (fixation duration mean), waktu fiksasi pertama pada AOI (time to first fixation). (Jacob and Karn, 2003).

\section{Metodologi Penelitian}

Jenis penelitian yang dilakukan merupakan jenis penelitian asosiatif dengan pendekatan kuantitatif. Pada penelitian ini, peneliti mencari hubungan antara indikator-indikator usability testing seperti time on task dan difficulty ratings dengan metrik-metrik eye tracking seperti number of fixation, fixation duration mean, time to first fixation.

\section{Alat dan Bahan Penelitian}

Alat yang digunakan dalam penelitian adalah sebagai berikut:

a. Perangkat keras berupa The Eye Tribe, USB 3.0, PC spesifikasi Processor I5 with Intel UHD Graphics 630 RAM 8 GB.

b. Perangkat lunak berupa Sistem Operasi Windows 10, Aplikasi OGAMA Version 5, Aplikasi The Eye Tribe V.0.9.77, Microsoft Excel 2016

Bahan yang digunakan dalam penelitian adalah sebagai berikut:

a. Halaman website Amazon.com 
Vol.2 No.2, Desember 2019

b. Kuisoner PSSUQ (Post Study System Usability Questionnaire).

\section{Teknik Pengumpulan Data}

Pengumpulan data dilakukan dengan melakukan observasi langsung, kuisioner dilakukan untuk memperkuat bahwa Amazon.com layak digunakan bagi perspektif pengguna dan wawancara untuk memastikan bahwa hasil dari pergerakan mata partisipan saat pengujian sama dengan pendapat atau persepsi masing-masing partisipan.

\section{Prosedur Pengujian}

Adapun prosedur pengujian yang dilakukan antara peneliti dan partisipan sebagai berikut:

a. Peneliti menjelaskan alur skenario pengujian kepada partisipan.

b. Perekam pengujian dilakukan menggunakan eye tracking yaitu the eye tribe dan aplikasi OGAMA.

c. Setelah pengujian, peneliti akan mewawancarai partisipan.

d. Memberikan penilaian tingkat kesulitan tugas (difficulty ratings) yaitu skor 1-3 "sulit" dan skor 4-5 "mudah".

e. Partisipan mengisi form kuisioner.

\section{Variabel Pengukuran}

Didalam pengujian ini mengkombinsikan 2 metode yaitu usability testing dan eye tracking. Dimana indikator usability testing terdiri dari time on task (waktu yang dibutuhkan partisipan dalam menyelesaikan tugas) dan difficulty ratings (tingkat kesulitan tugas) kemudian metrik eye tracking terdiri dari number of fixation, fixation duration mean dan time to first fixation.

Pada penelitian sebelumnya, $J$ wang et al (2018) hubungan antara 2 indikator usability testing dan metrik eye tracking (number of fixation) telah dibuktikan bahwa terdapat korelasi atau hubungan pada masing-masing variabel. Sehingga dalam penelitian ini akan mencari hubungan antara variabel yang belum diukur yaitu 2 indikator usability testing dengan 2 metrik eye tracking (fixation duration mean dan time to first fixation). Adapun hipotesis dalam penelitian ini adalah sebagai berikut:

1. H0 : Tidak ada hubungan antara Time On

Task dan Fixation Duration Mean.

Ha : Terdapat hubungan antara Time On Task dan Fixation Duration Mean.
2. H0 : Tidak ada hubungan antara Time On Task dan Time To First Fixation.

Ha : Terdapat hubungan antara Time On Task dan Time To First Fixation.

3. H0 : Tidak ada hubungan antara Difficulty Ratings dan Fixation Duration Mean.

Ha : Terdapat hubungan antara Difficulty Ratings dan Fixation Duration Mean.

4. H0 : Tidak ada hubungan antara Difficulty Ratings dan Time To First Fixation.

$\mathrm{Ha}$ : Terdapat hubungan antara Difficulty Ratings dan Time To First Fixation.

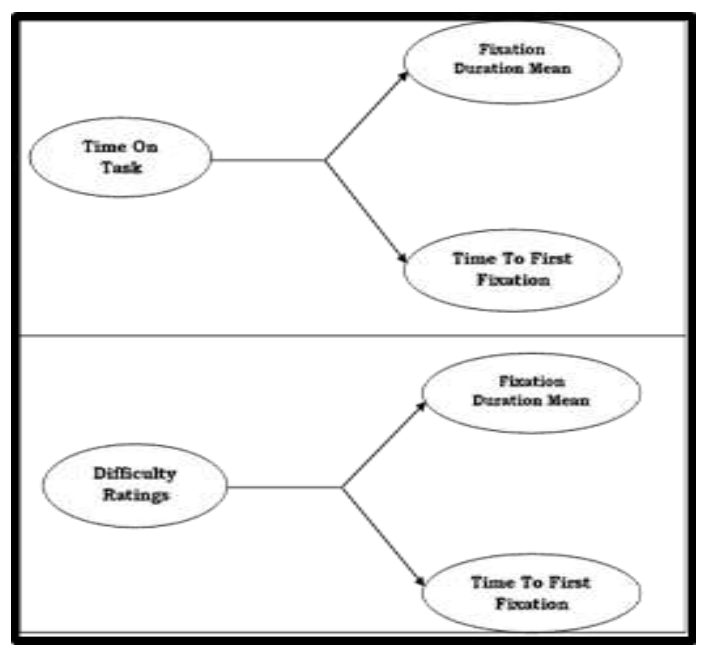

Gambar 1. Variabel Korelasi Penelitian

\section{Partisipan}

Dalam penelitian ini, Teknik sampling yang digunakan adalah teknik sampling purposive. Teknik ini dilakukan dengan cara mengambil subjek berdasarkan pertimbangan atau tujuan tertentu. (Sugiyono, 2017). Jumlah sampel yang diambil adalah 30 partisipan sebab penelitian ini terkait penelitian korelasi. Menurut Gay, Mills dan Airasian sampel yang digunakan untuk penelitian korelasi diperlukan sampel sebesar 30 partisipan. (Gay, Mills and Airasian, 2012).

\section{Teknik Analisis Data}

\section{Korelasi Pearson Product Moment}

Teknik korelasi ini digunakan untuk mencari hubungan dan membuktikan hipotesis hubungan dua variabel bila data kedua variabel berbentuk interval atau ratio, dan sumber data dari dua variabel atau lebih tersebut adalah 
sama (Sugiyono, 2017). Berikut rumus korelasi product moment:

$$
\boldsymbol{r x y}=\frac{n \sum x y-\left(\sum x\right)\left(\sum y\right)}{\sqrt{\left[\left\{n \sum x^{2}-\left(\sum x\right)^{2}\right\}\left\{n \sum y^{2}-\left(\sum y\right)^{2}\right\}\right]}}
$$

Tabel 1. Interval Koefisien Korelasi

\begin{tabular}{cc}
\hline Interval Koefisien & Tingkat Hubungan \\
\hline $0,00-0,199$ & Sangat Rendah \\
$0,20-0,399$ & Rendah \\
$0,40-0,599$ & Sedang \\
$0,60-0,799$ & Kuat \\
$0,80-1,000$ & Sangat Kuat \\
\hline
\end{tabular}

Jika rxy $\leq+1$ dinyatakan terdapat hubungan sempurna atau kuat searah, $\mathrm{rxy} \leq-1$ dinyatakan terdapat hubungan sempurna atau kuat berlawanan arah, jika $\mathrm{rxy}=0$ maka dinyatakan tidak adanya hubungan atau korelasi. (Sembiring, 1995).

\section{Uji Signifikansi}

Untuk melihat signifikansi korelasi atau tidak dilakukan dengan cara maka dihitung nilai $\mathrm{t}$, dapat dikatakan $\mathrm{t}$ hitung $>\mathrm{t}$ tabel maka korelasi dinyatakan signifikan. Adapun rumus untuk mencari nilai $\mathrm{t}$ hitung atau nilai signifikansi:

$$
t=\frac{r \sqrt{n-2}}{\sqrt{1-r^{2}}}
$$

Tabel 2. Task dan Skenario Pengujian

\section{No. Task and Scenario}

1. Cobalah temukan dan cari fitur $\mathbf{L O G I N}$ pada website tersebut.

2. Cobalah temukan fitur SORT BY pada website tersebut.

3. Cobalah temukan dan cari fitur

SEARCHING pada website tersebut

4. Cobalah temukan fitur FILTER pada

$$
\text { website tersebut. }
$$

5. Cobalah temukan fitur ADD TO CART pada website tersebut.

\section{Hasil dan Pembahasan}

\section{Hasil Pengujian Usability Testing}

Pada usability testing terdapat 2 indikator yang diukur yaitu waktu penyelesaian tugas (time on task) dan tingkat kesulitan tugas (difficulty ratings).

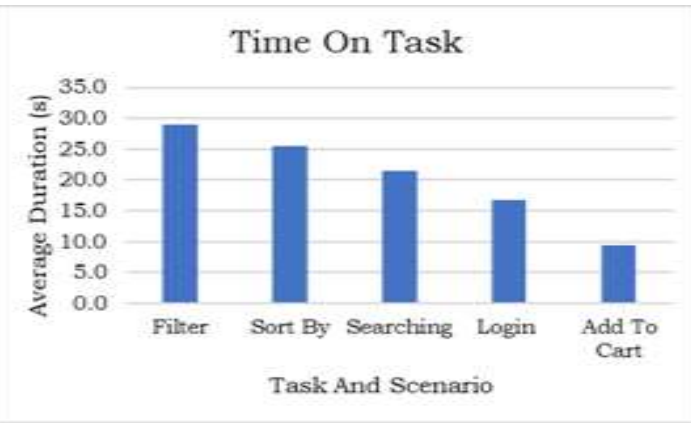

Gambar 2. Rekapitulasi Time On Task

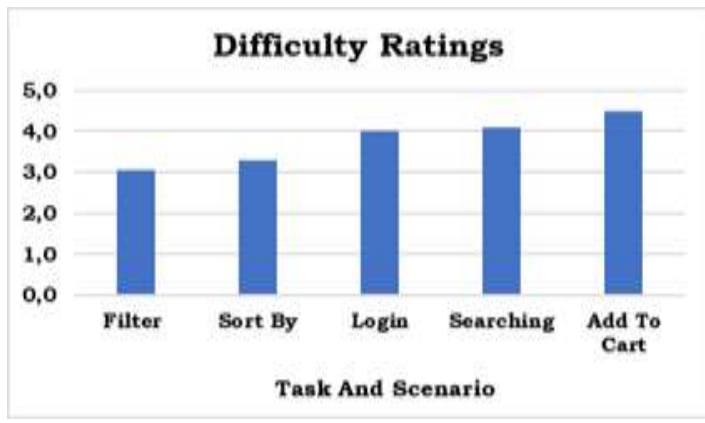

Gambar 3. Rekapitulasi Difficulty Ratings

Berdasarkan Gambar 2 dan 3, Menurut Cooke (2006), suatu fitur yang effisien akan menghasilkan waktu penyelesaian tugas yang singkat. (Cooke, 2006). Dalam pengujian partisipan menilai bahwa skenario filter dan sort by tergolong "sulit" dengan rata-rata difficulty ratings berada diangka 4 yaitu 2,6 dan 3,1 . Sehingga menghambat mereka dalam menyelesaikan skenario walaupun membutuhkan waktu yang lama sampai mereka menyelesaikan tugas yang diminta, dari hasil rata-rata filter dan sort by memiliki rata-rata waktu yang lama yaitu 29 detik dan 25,5 detik. Sedangkan 3 fitur lainnya tergolong "mudah" seperti add to cart memiliki rata-rata waktu 9,4 
Vol.2 No.2, Desember 2019

detik dengan rata-rata difficulty ratings 4,4 , searching 21,5 detik dengan rata-rata kesulitan tugas 4,1 dan login 16,7 detik dengan rata-rata 4,07 .

\section{Hasil Pengujian Eye Tracking}

Eye tracking merupakan suatu pengujian yang dilakukan untuk merekam pergerakan mata, titik fokus partisipan.

\section{Number Of Fixation}

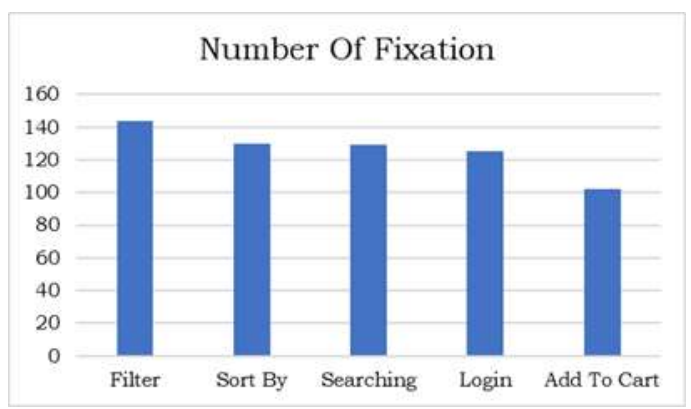

Gambar 4. Rekapitulasi Number Of Fixation

Berdasarkan Gambar 4. Number of fixation atau Jumlah fiksasi yang besar menunjukkan bahwa partisipan mencoba atau berusaha mencari objek yang diminta dengan kata lain jumlah fiksasi yang besar dikaitkan dengan pencarian visual pengguna bahwa objek yang dituju kurang effisien dari segi tampilannya. (Goldberg and Kotval, 1999), dari hasil data pelacakan mata mengindikasikan bahwa skenario filter memiliki jumlah fiksasi paling banyak dibandingkan dengan tugas-tugas yang lainnya sebesar 144 jejak mata, sedangkan sort by menempati posisi kedua juga dengan jumlah fiksasi terbanyak yaitu sebesar 130 jejak mata.

\section{Fixation Duration Mean}

Berdasarkan Gambar 5. Dapat dikatakan fixation duration mean atau rata-rata durasi fiksasi yang terjadi adalah sort by memiliki rata-rata terlama sebesar $1037,6 \mathrm{~ms}$, filter memiliki rata-rata $767,5 \mathrm{~ms}$, add to cart memiliki rata-rata $741,4 \mathrm{~ms}$, login memiliki rata-rata $636,1 \mathrm{~ms}$, searching memiliki rata-rata $609,4 \mathrm{~ms}$.

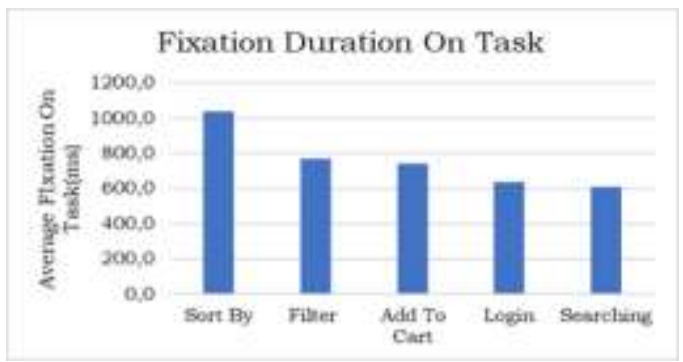

Gambar 5. Rekapitulasi Fixation Duration Mean

\section{Time To First Fixation}

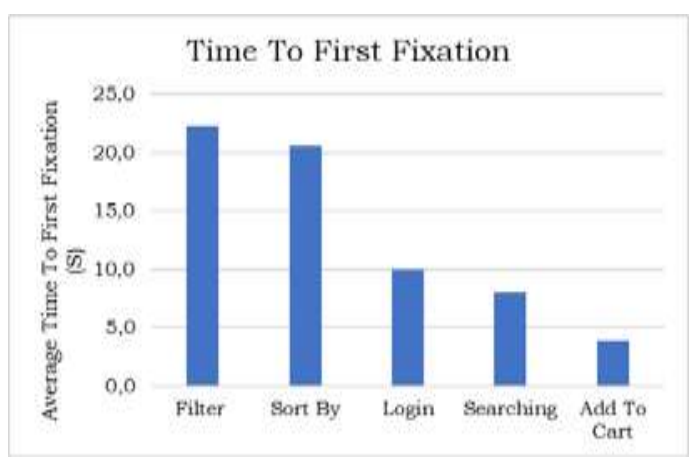

Gambar 6. Rekapitulasi Time To First Fixation

Berdasarkan Gambar 6. Bahwa time to first fixation merupakan waktu pertama terjadinya fiksasi pada AOI masing-masing skenario, Time to first fixation atau waktu fiksasi pertama pada fitur yang di uji dikatakan effisien jika memperoleh waktu pertama fiksasi dengan cepat dalam menemukan fitur. (Poole and Ball, 2005). Pada hasil rekapitulasi skenario filter memiliki rata-rata 22,3 detik, sort by memiliki rata-rata 20,6 detik, login memiliki rata-rata 10 detik, searching memiliki rata-rata 8,1 detik dan add to cart memiliki rata-rata 3,9 detik.

\section{Hasil Uji Korelasi Pearson Product Moment}

Didalam uji korelasi ini terdapat 2 variabel yang akan diuji hubungannya yaitu variabel usability testing terdiri dari time on task dan difficulty ratings kemudian variabel eye tracking seperti number of fixation, fixation duration mean dan time to first fixation. Untuk mengetahui hubungan antar 2 variabel signifikan atau tidak maka dihitung nilai $\mathrm{t}$ dan membandingkan dengan nilai $\mathrm{t}$ tabel, nilai $\mathrm{t}$ tabel yang didapatkan sebesar 2,048. Sehingga 
Vol.2 No.2, Desember 2019

dapat dikatakan jika nilai t hitung > 2,048 maka korelasi dinyatakan signifikan, begitu sebaliknya. Berikut hasil korelasinya:

Tabel 3. Hasil Korelasi Indikator Usability Testing dan Metrik Eye Tracking

\begin{tabular}{|c|c|c|c|c|c|c|}
\hline No. & & Login & Sort By & Searching & Filter & $\begin{array}{c}\text { Add To } \\
\text { Cart }\end{array}$ \\
\hline \multirow[t]{2}{*}{1} & $\begin{array}{l}\text { Time On Task Dengan } \\
\text { Number Of Fixation }\end{array}$ & 0.349 & 0.605 & 0.333 & 0.674 & 0.345 \\
\hline & t hitung & 1.970 & 4.017 & 1.867 & 4.832 & 1.942 \\
\hline \multirow[t]{2}{*}{2} & $\begin{array}{c}\text { Difficulty Ratings Dengan } \\
\text { Number Of Fixation }\end{array}$ & -0.020 & -0.669 & 0.126 & -0.356 & -0.503 \\
\hline & t hitung & 0.104 & 4.761 & 0.671 & 2.014 & 3.079 \\
\hline \multirow[t]{2}{*}{3} & $\begin{array}{l}\text { Time On Task Dengan } \\
\text { Difficulty Ratings }\end{array}$ & -0.433 & -0.759 & -0.435 & -0.670 & -0.658 \\
\hline & t hitung & 2.539 & 6.162 & 2.558 & 4.775 & 4.619 \\
\hline \multirow[t]{2}{*}{4} & $\begin{array}{c}\text { Time On Task Dengan } \\
\text { Fixation Duration Mean }\end{array}$ & -0.021 & -0.410 & 0.372 & 0.224 & 0.290 \\
\hline & t hitung & 0.110 & 2.379 & 2.123 & 1.213 & 1.602 \\
\hline \multirow[t]{2}{*}{5} & $\begin{array}{l}\text { Time On Task Dengan } \\
\text { Time To First Fixation }\end{array}$ & 0.723 & 0.854 & 0.366 & 0.974 & 0.441 \\
\hline & t hitung & 5.540 & 8.693 & 2.078 & 22.595 & 2.598 \\
\hline \multirow[t]{2}{*}{6} & $\begin{array}{c}\text { Difficulty Ratings Dengan } \\
\text { Fixation Duration Mean }\end{array}$ & -0.117 & 0.540 & -0.069 & -0.004 & -0.388 \\
\hline & t hitung & 0.625 & 3.397 & 0.364 & 0.020 & 2.229 \\
\hline \multirow[t]{2}{*}{7} & $\begin{array}{c}\text { Difficulty Ratings Dengan } \\
\text { Time To First Fixation }\end{array}$ & -0.380 & -0.661 & -0.241 & -0.704 & -0.318 \\
\hline & t hitung & 2.172 & 4.667 & 1.311 & 5.246 & 1.775 \\
\hline
\end{tabular}

\section{Korelasi Antara Time On Task dengan Number Of Fixation}

Dimana pada hasil pengujian korelasi antara time on task dan number of fixation menunjukkan bahwa banyaknya titik fiksasi yang dihasilkan akan menghasilkan waktu yang lama dalam menyelesaikan tugas sehingga arah korelasinya searah atau positif. Teridentifikasi korelasi positif kuat yang signifikan pada 2 task yang menghasilkan waktu dan titik fiksasi yang banyak yaitu filter ( $\mathrm{r}: 0,674$; $\mathrm{t}$ hitung $>\mathrm{t}$ tabel : 4,832) dan sort by ( $\mathrm{r}: 0,605$; $\mathrm{t}$ hitung $>\mathrm{t}$ tabel : 4,017). Kemudian terdapat korelasi positif rendah yang tidak signifikan pada 3 task yaitu login (r : 0,349; t hitung < t tabel : 1,97), add to cart $(\mathrm{r}: 0,345 ; \mathrm{t}$ hitung $<\mathrm{t}$ tabel : 1,942) dan searching ( $\mathrm{r}$ : 0,333; $\mathrm{t}$ hitung $<\mathrm{t}$ tabel : 1,867). Didalam penelitian J. Wang ET AL menyatakan adanya korelasi atau hubungan antara number of fixation dengan time on task. Dari hasil wawancara didapatkan pencarian fitur filter dan sort by yang lama untuk ditemukan.

\section{Korelasi Antara Difficulty Ratings dengan Number Of Fixation}

Hasil menunjukkan banyaknya titik fiksasi yang dihasilkan akan mendapatkan nilai tingkat kesulitan yang kecil pula. Terdapat korelasi negatif kuat yang signifikan yaitu sort 
by (r : -0,669; $\mathrm{t}$ hitung > t tabel : 4,761), korelasi negatif sedang yang signifikan yaitu add to cart ( $\mathrm{r}:-0,503$; $\mathrm{t}$ hitung $>\mathrm{t}$ tabel : 3,079), terdapat korelasi negatif rendah dan sangat rendah yang tidak signifikan yaitu filter ( $\mathrm{r}:-0,356$; $\mathrm{t}$ hitung $<\mathrm{t}$ tabel : 2,014) dan login ( $\mathrm{r}:-0,020 ; \mathrm{t}$ hitung $<\mathrm{t}$ tabel : 0,104), kemudian terdapat korelasi positif sangat rendah yang tidak signifikan yaitu searching ( $\mathrm{r}:$ 0,126: $\mathrm{t}$ hitung < $\mathrm{t}$ tabel : 0,671). J. Wang ET AL menyatakan adanya korelasi atau hubungan antara number of fixation dan difficulty ratings. Dari hasil wawancara, partisipan menilai 2 fitur seperti sort by dan filter tergolong sulit, kemudian 3 fitur lainnya tergolong mudah.

\section{Korelasi Antara Time On Task dengan}

\section{Difficulty Ratings}

Dari hasil pengujian semakin lama waktu penyelesaian tugas maka semakin kecil nilai kesulitan tugas yang didapatkan sehingga arah korelasinya berlawanan arah atau negatif, terdapat korelasi negatif kuat yang signifikan pada 3 task yaitu sort by (r : -0,759; t hitung > $\mathrm{t}$ tabel : 6,162), filter $(\mathrm{r}:-0,670: \mathrm{t}$ hitung $>\mathrm{t}$ tabel : 4,775) dan add to cart ( $\mathrm{r}:-0,658 ; \mathrm{t}$ hitung $>\mathrm{t}$ tabel : 4,619). Kemudian terdapat korelasi negatif sedang yang signifikan pada 2 task yaitu searching $(\mathrm{r}:-0,435 ; \mathrm{t}$ hitung $>\mathrm{t}$ tabel : 2,558) dan $\operatorname{login}(\mathrm{r}:-0,433$; t hitung $>\mathrm{t}$ tabel : 2,539). J Wang ET AL menyatakan terdapat korelasi atau hubungan antara time on task dan difficulty ratings. Dari hasil wawancara yang didapatkan 2 fitur yaitu filter dan sort by tergolong sulit dan waktu yang dihasilkan lama.

\section{Korelasi Antara Time On Task dengan}

\section{Fixation Duration Mean}

Dari hasil perhitungan diperoleh korelasi positif dan negatif pada fixation duration mean dengan time on task, Terdapat 1 task dengan korelasi positif rendah yang signifikan yaitu searching $(\mathrm{r}: 0,372$; $\mathrm{t}$ hitung $>\mathrm{t}$ tabel : 2,123), terdapat 2 task dengan korelasi positif rendah yang tidak signifikan yaitu filter $(\mathrm{r}: 0,224 ; \mathrm{t}$ hitung < $\mathrm{t}$ tabel : 1,213) dan add to cart $(\mathrm{r}$ : 0,290; $\mathrm{t}$ hitung $<\mathrm{t}$ tabel : 1,602). Kemudian terdapat 1 korelasi negatif signifikan yaitu sort by $(\mathrm{r}:-0,410$; $\mathrm{t}$ hitung $>\mathrm{t}$ tabel $: 2,379)$ dan 1 korelasi negatif sangat rendah tidak signifikan yaitu $\operatorname{login}(\mathrm{r}:-0,021$; $\mathrm{t}$ hitung $<\mathrm{t}$ tabel : 0,11$)$.

\section{Korelasi Antara Time On Task dengan}

\section{Time To First Fixation}

Dari hasil uji korelasi time to first fixation dengan time on task semakin lama waktu fiksasi pertama yang dihasilkan semakin lama juga waktu penyelesaian tugas yang diselesaikan. Teridentifikasi korelasi positif pada semua task yang dimana 2 task diidentifikasi terdapat korelasi positif sangat kuat yang signifikan yaitu filter $(\mathrm{r}: 0,974 ; \mathrm{t}$ hitung $>\mathrm{t}$ tabel $: 22,595)$, sort by $(\mathrm{r}: 0,854 ; \mathrm{t}$ hitung $>\mathrm{t}$ tabel : 8,693). 1 task terdapat korelasi positif kuat yang signifikan yaitu login $(\mathrm{r}: 0,723$; $\mathrm{t}$ hitung $>\mathrm{t}$ tabel : 5,54), korelasi positif sedang yang signifikan terdapat pada 1 task yaitu add to cart ( $\mathrm{r}$ : 0,441 ; t hitung > t tabel : 2,598) dan 1 task korelasi positif lemah signifikan yaitu searching ( $\mathrm{r}: 0,366$; $\mathrm{t}$ hitung $>\mathrm{t}$ tabel $: 2,078$ ). Dari hasil wawancara, sort by dan filter menghasilkan waktu fiksasi dan penyelesaian yang lama daripada 3 fitur lainnya seperti login, searching dan add to cart.

\section{Korelasi Antara Difficulty Ratings Dengan Fixation Duration Mean}

Hasil dari korelasi fixation duration mean dengan difficulty ratings terdapat 1 korelasi positif sedang yang signifikan yaitu sort by $(\mathrm{r}$ : 0,540; t hitung > t tabel : 3,397), terdapat 1 korelasi negatif lemah yang signifikan yaitu add to cart ( $\mathrm{r}$ : $-0,388$; $\mathrm{t}$ hitung $>\mathrm{t}$ tabel : 2,229), kemudian terdapat 3 korelasi negatif sangat lemah tidak signifikan yaitu login ( $\mathrm{r}$ : $0,117$; $t$ hitung $<\mathrm{t}$ tabel : 0,625$)$, searching $(\mathrm{r}$ : $-0,069$; $\mathrm{t}$ hitung $<\mathrm{t}$ tabel : 0,364) dan filter $(\mathrm{r}$ : $-0,004$; $\mathrm{t}$ hitung $<\mathrm{t}$ tabel $: 0,02$ ).

\section{Korelasi Antara Difficulty Ratings Dengan Time To First Fixation}

Hasil difficulty ratings dengan time to first fixation, semakin lama waktu fiksasi pertama yang dihasilkan akan kecil pula nilai tingkat kesulitan tugas yang dihasilkan dimana arah korelasinya berlawanan arah atau negatif. Teridentifikasi korelasi negatif yang dimana berlaku pada semua skenario, hasil menunjukkan terdapat 2 task teridentifikasi korelasi negatif kuat yang signifikan yaitu 
filter ( $\mathrm{r}:-0,704$; $\mathrm{t}$ hitung $>\mathrm{t}$ tabel : 5,246) dan sort by ( $\mathrm{r}:-0,661$; $\mathrm{t}$ hitung $>\mathrm{t}$ tabel : 4,667). Terdapat 1 task dengan korelasi negatif rendah yang signifikan yaitu $\operatorname{login}(\mathrm{r}:-0,380$; $\mathrm{t}$ hitung $>\mathrm{t}$ tabel : 2,172). Kemudian terdapat 2 task dengan korelasi negatif rendah tidak signifikan yaitu searching $(\mathrm{r}:-0,241$; $\mathrm{t}$ hitung $>\mathrm{t}$ tabel : 1,311) dan add to cart $(\mathrm{r}:-0,318$; $\mathrm{t}$ hitung $>\mathrm{t}$ tabel : 1,775). Dari hasil wawancara, 2 fitur seperti sort by dan filter diberikan penilaian kesulitan tugas yang tegolong sulit dan menghasilkan waktu fiksasi pertama yang lama sedangkan 3 fitur lainnya seperti login, searching dan add to cart tergolong mudah juga menghasilkan waktu fiksasi pertama yang cepat.

Maka dari hasil pengujian korelasi dapat diputuskan hasil hipotesisnya:

a. Terdapat hubungan antara time on task dan fixation duration mean maka $\mathrm{H} 0$ tidak diterima dan HA diterima.

b. Terdapat hubungan antara time on task dan time to first fixation maka $\mathrm{H} 0$ tidak diterima dan HA diterima.

c. Terdapat hubungan antara difficulty ratings dan fixation duration mean maka H0 tidak diterima dan HA diterima.

d. Terdapat hubungan antara difficulty ratings dan time to first fixation maka $\mathrm{H} 0$ tidak diterima dan HA diterima.

\subsection{Hasil Kuisioner}

Pengisian kuisioner tidak ada kaitan dengan korelasi penelitian yang dicari, tetapi kuisioner dilakukan untuk memastikan dan memperkuat bahwa website amazon.com layak digunakan menurut perspektif atau pandangan pengguna. Dari hasil hitung Nilai presentase akhir dari kuisioner PSSUQ yang didapatkan memiliki rata-rata $75 \%$ yang artinya website amazon.com dapat dikategorikan baik berdasarkan pendapat, persepsi partisipan terhadap tugas-tugas pengujian yang telah dilakukan dan website ini dapat dikatakan layak digunakan menurut pandangan pengguna.

\subsection{Hasil Wawancara}

Setelah pengujian selesai akan dilakukan wawancara dengan memperlihatkan video replay guna untuk memastikan bahwa hasil dari pergerakan mata partisipan saat pengujian sama dengan pendapat atau persepsi masingmasing partisipan. Data kualitatif menambah nilai pada pengukuran kinerja dan data pergerakan mata dengan mengungkapkan sesuatu dari harapan dan persepsi pengguna juga memberikan informasi tentang sesuatu yang disukai dan harapan pengguna. (Tzanidou, 2005). Berikut hasil rekapan masalah dan solusi dari wawancara:

Tabel 4. Masalah dan Solusi Website Amazon.com

\section{Deskripsi masalah usability website}

Task 1 : Temukan fitur login

a. Fitur login hanya sekedar tulisan, tidak

adanya penanda itu ada fitur untuk

login.

\section{Task 2 : Temukan fitur sort by}

a. Tulisan sort by terlalu kecil.

b. Sort by terpisah dengan area filter.

c. Fitur sort by berdiri sendiri di area yang cukup luas sehingga membingungkan.

d. Posisi sort by yang terlalu menjorok kekanan menyulitkan saat proses pencarian.

\section{Solusi}

- Menambahkan ikon pada fitur login
- Ukuran font yang kecil sangat tidak nyaman sehingga disarankan menambah ukuran font pada sort by.

- Sort by seharusnya digabungkan pada area filter walaupun berbeda fungsi tetapi sort by juga termasuk fitur memampatkan informasi detail juga.

- Menambahkan ikon pada sort by. 
Vol.2 No.2, Desember 2019

e. Tidak ada ikon sort by pada halaman tersebut.

Task 4 : Temukan fitur filter

a. Filter tidak seperti informasi detail dalam memberikan informasi khusus dalam proses pencarian melainkan seperti kata-kata yang diletakkan dikiri halaman sehingga membingungkan.

b. Area filter yang di scroll kebawah untuk menyaring informasi-informasi khusus sehingga menyulitkan pengguna dalam menfilter apa yang diinginkan.

c. Tidak ada ikon filter

d. Filter terpisah dengan sort by

e. Terlalu banyak tulisan sehingga membuat para partisipan malas untuk mencari area filter tersebut.

f. Letak atau posisi kurang tepat yang menjorok kekiri kebawah.

g. Tulisan filter tidak ada.

h. Semua area filter bagaikan deskripsi yang menyulitkan.
- Seharusnya filter mempunyai area

tersendiri dan pengelompokkan

informasi dibuat seperti pilihan.

- Menambahkan ikon pada filter

- Letak atau posisi filter seharusnya diatas halaman atau area khusus untuk fitur filter.

- Seharunya filter digabungkan dengan area sortby

- Menambah tulisan filter pada area.
Task 5 : Temuan fitur Add To Cart

a. Fitur add to cart memiliki ukuran tabel yang kecil.

b. Ukuran font yang kecil.

\section{Kesimpulan}

Berdasarkan pada hasil analisis dan pembahasan yang telah dikemukakan kesimpulan dari penelitian ini ialah dengan jumlah partisipan 30 orang dari hasil pengujian pada indikator usability testing, bahwa fitur filter dan sort by mendapatkan nilai tingkat kesulitan tugas atau difficulty ratings tergolong sulit dan memiliki waktu penyelesaian tugas atau time on task yang lama karena kedua fitur tersebut sulit untuk ditemukan sehingga dikatakan kurang effisien. Hasil pada metrik eye tracking, jumlah titik fiksasi atau number
- Ukuran tabel add to cart diperbesar.

- Menambahkan ukuran font add to cart. of fixation dan rata-rata waktu fiksasi atau fixation duration mean pada fitur sort by memiliki titik waktu yang banyak dan lama sehingga tergolong tidak effisien. Sedangkan waktu fiksasi pertama saat menemukan fitur atau time to first fixation fitur sort by dan filter mendapatkan waktu fiksasi pertama tergolong lama sedangkan fitur login, searching, add to cart memiliki memiliki waktu fiksasi pertama tergolong cepat sehingga ketiga fitur tersebut tergolong effisien. Hasil pengujian korelasi pearson product moment didapatkan korelasi atau hubungan antara time on task dengan fixation duration mean, time on task dengan 
Vol.2 No.2, Desember 2019

time to first fixation, difficulty ratings dengan fixation duration mean, difficulty ratings dengan time to first fixation. Ada dua kemungkinan indikator pengukuran kinerja usability dengan eye tracking membuktikan adanya korelasi yang signifikan berarti pengukuran usability menggunakan eye tracking dapat dijadikan alternatif dalam melakukan pengukuran usability yang lebih akurat dengan tingkat signifikansi > 2,048 pada penelitian selanjutnya.

\section{Daftar Pustaka}

Bergstrom, Ph.D, J. R., \& Schall, A. J. (2014). Eye Tracking in User Experience Design. Library of Congress Cataloging-inPublication Data. USA.

Cooke, L. (2006) 'Is Eye Tracking The Next Step In Usability Testing?', IEEE International Professional Communication Conference, 00(C), pp. 236-242.

Ehmke, Claudia, and Stephanie Wilson. 2007. "Identifying Web Usability Problems From Eye Tracking Data". the British Computer Society People and Computers. London.

Gay, L. R., Mills, G. E., \& Airasian, P. (2012). Educational Research : Competencies For Analysis. Pearson Education, Inc. New Jersey.

Goldberg, J. H. and Kotval, X. P. (1999) 'Computer interface evaluation using eye movements: Methods and constructs', International Journal of Industrial Ergonomics, 24(6), pp. 631-645.

ISO-9241-11. (1998). Ergonomic Requirements For Office Work With Visual Display Terminals (VDTs). International Organization For Standardization

Jacob , R. J., \& Karn, K. S. (2003). Eye Tracking in Human-Computer Interaction and Usability Research: Ready to Deliver the Promises. Elsevier Science $B V$.

Krug, S. (2010). Rocket Surgery Made Easy: The Do-It-Yourself Guide to Finding and Fixing Usability Problems. New Riders. California.
Poole, A. and Ball, L. J. (2005) 'Eye Tracking in Human-Computer Interaction and Usability Research: Current Status and Future Prospects', United Kingdom: Psychology Department, Lancaster University., pp. 211-219.

Similarweb. Website Traffic Statistics \& Market $\quad 2019$. (https://www.similarweb.com diakses pada 11 Desember 2019).

Sembiring, R. K. (1995). Analisis Regresi. Bandung: ITB.

Sugiyono. (2017). Statistika Untuk Penelitian. Alfabeta. Bandung.

Sugiyono, P. D. (2016). Metode Penelitian Kuantitatif, Kualitatif Dan $R \& D$. Alfabeta. Bandung.

Tullis, T., \& Albert, B. (2008). Measuring The User Experience Collecting, Analyzing And Presenting Usability Metrics. Elsevier Inc. USA.

Tzanidou, E. (2006) 'Evaluating Usability of E-commerce Sites By Tracking Eye Movements'. United Kingdom.

Voßkühler, A. (2009) 'OGAMA Description (for Version 2.5). A Software To Record, Analyze and Visualize Gaze and Mouse Movements In Screen Based Environments.' Arnimallee. Berlin.

Wang, J. et al. (2018) 'Exploring Relationships Between Eye Tracking and Traditional Usability Testing Data', International Journal of Human-Computer Interaction. Taylor \& Francis, 35(6), pp. 483-494. 